\title{
Establishing Benchmarks For Success In Golf Facilities
}

Joseph M. Groch, Hodges University, USA

\begin{abstract}
With a $17 \%$ reduction in golfers over the last decade and a $19 \%$ turnover rate among golf facility managers, the golf industry is in decline. The purpose of this study was to establish a more universal method of measuring success in the golf industry in Southwest Florida (SWFL) beyond traditional financial measures in order to improve organizational outcomes. The research defined "organizational effectiveness" from a multidimensional approach which included five pillars: financial, environmental, philanthropic, customer satisfaction, and employee satisfaction. The research indicated that the three main drivers of organizational effectiveness in SWFL were: customer satisfaction, employee satisfaction and environmental responsibility. The implications of these finding could be significant to auditors searching for indicators of fraud, or managers looking for trends, or board of directors trying to assess the competency of the management team.
\end{abstract}

Keywords: Success In The Golf Industry; Golf Management; Benchmarks For Success

\section{INTRODUCTION}

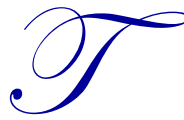

he golf industry has experienced a $17 \%$ decline in golfers over the last decade and a $19 \%$ turnover rate among golf facility managers (NGF, 2012). Specifically, the number of golfers in the U.S. has decreased from 30.6 million in 2005 to 25.7 million in 2011, (NGF, 2012) and the 5 year retention rate for golfers during the same period is only $54 \%$ for men and $33 \%$ for women (PGA, 2012). This sharp decline in players poses a real threat to the industry.

The purpose of this study is to posit a method for measuring effective golf facilities in Southwest Florida (SWFL). The goal is to establish broader benchmarks for success than the traditional income statement and balance sheet. This becomes especially significant in light of the numerous non-profit organizations in the golf industry. While financial factors will be considered, this study will view "organizational effectiveness" from a multidimensional outlook which includes Five Pillars: Financial, Environmental, Philanthropic, Customer Satisfaction, and Employee Satisfaction (Figure 2.).

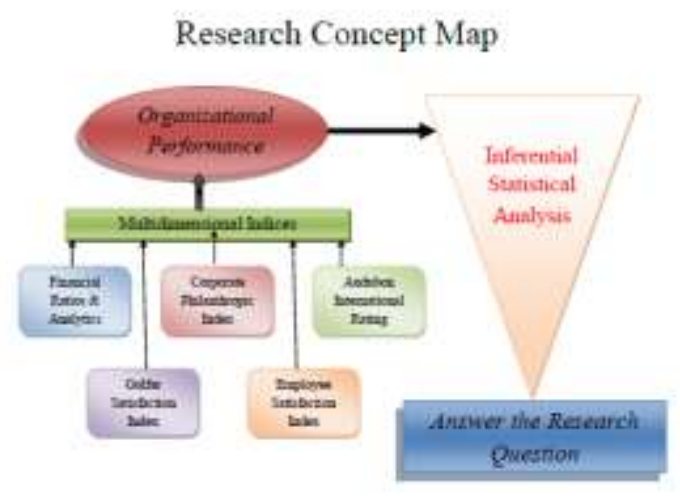

Figure 1 - Conceptual Framework 
The research was conducted among ten golf facilities in Southwest Florida (SWFL) which included private, public, resort and golf communities. Two hundred thirty-seven golfers participated in the golfer satisfaction survey, 121 employees participated in the employee satisfaction survey, while 27 managers participated in interviews. Data was accumulated and analyzed using IBM's Statistical Package for the Social Science (SPSS) version 21.

\section{LITERATURE REVIEW}

The need for a multidimensional approach to defining and assessing organizational effectiveness has been identified for more than 40 years. As pointed out by Yuchtman and Seashore (1967):

Since resources are of various kinds, and the competitive relationships are multiple, and since there is interchangeability among classes of resources, the assessment of organizational effectiveness must be in terms not of any single criterion but of an open-ended multidimensional set of criteria (p. 891).

More recently, there has been a focus on expanding the measures of organizational effectiveness to include factors such as corporate social responsibility (CSR). In 1994, John Elkington coined the phrase the Triple Bottom Line (TBL) which focuses on a more comprehensive approach to organizational effectiveness that measures the interrelated dimensions of financial, social, and environmental factors, or sometimes referred to as profit, people, and planet (Elkington, 1994). However, some scholars including Henderson (2001) and Karnani (2010), both disagree with the goals of CSR. They believe it is artificial, citing arguments similar to Adam Smith's "invisible hand" theory that markets should determine how and where resources should be allocated. Nevertheless, according to Brody (1995), TBL can be very useful especially in non-profit organizations (like most country clubs).

While many scholars support the concept of multidimensional measures such as TBL, there are difficulties in establishing a common unit of measure. According to Slaper and Hall (2011), "There is no universal standard method for calculating the TBL. Neither is there a universally accepted standard for the measures that comprise each of the three TBL categories." However, Slaper and Hall (2011) go on to posit that this is an advantage to TBL because it allows practitioners and users to adapt a model that is most appropriate for their industry or organization.

Models, however, do exist including: the financial ratio models of Edwards (1998); the Corporate Philanthropic Index (CPI) of the Council on Foundations (2000); the Golfer Satisfaction Index (GSI) of Groch (2012), the Index of Employee Satisfaction (IES) of Brayfield (1951) and the Audubon International Cooperative Sanctuary certification scale.

\section{BENEFITS TO MULTIDIMENSIONAL MEASURES}

In addition to TBL, other dimensions of non-financial measures have also proven to be beneficial to organizations. According to Frost (2013), financial goals drive higher profits, but non-financial company objectives help to improve the company as a whole. Also, these non-financial improvements assist in rounding out the company's strengths in areas like customer service, production quality, and employee satisfaction. Frost (2013), maintains that these areas create a stronger company that performs better in the market thereby increasing profits and sustainability. Other benefits to multidimensional measures were cited by Ittner and Larcker (2000) of the Wharton School of Business who state:

- $\quad$ Non-financial measures provide closer links to long-term organizational strategies

- $\quad$ Traditional measures are not effective because drivers of success in many industries are "intangible assets" such as intellectual capital and customer satisfaction and loyalty, rather than the "hard assets" allowed on balance sheets

- $\quad$ Non-financial measures can be better indicators of future financial performance

- $\quad$ Non-financial measures are less susceptible to external noise than accounting measures, therefore their use may improve managers' performance by providing more precise evaluation of their actions

This line of thinking has also gained the support of traditional accounting firms and financial institutions such a KPMG Peat Marwick, Deloitte Touche Tohmatsu International, Ernst and Young, and the Citibank Behavior 
Science Research Council. Many of these institutions contend that non- financial measures such as customer satisfaction, employee satisfaction, and innovation are not full captured in traditional accounting measures and should supplement financial measures in internal accounting systems (Ittner \& Larcker, 1998). Finally, non financial performance measures (NFPM) have been shown to be a significant fraud indicator which is not easily manipulated by the perpetrator (Brazel, Jones, Hall, \& Zimbelman, 2005).

\section{METHODOLOGY}

Research was conducted among 10 golf facilities in Southwest Florida (SWFL). A stratified random sample of 12 country clubs in Charlotte, Lee and Collier counties was selected among a population of approximately 120 clubs in order to generate a cluster sample of organizational effectiveness data and leadership attributes in the golf industry. Ten of 12 golf facilities ( $83 \%$ response rate) agreed to participate in the research. The sample was stratified to include public, private, resort and golf communities. Below is a breakdown of the survey distribution:

\begin{tabular}{cccc} 
Location & $\#$ & Facility & $\#$ \\
\hline Charlotte & 2 & Public & 1 \\
Lee & 3 & Private & 3 \\
Collier & 5 & Resort & 1 \\
& & Golf Community & 5
\end{tabular}

Path Analysis

Organizational Effectiveness

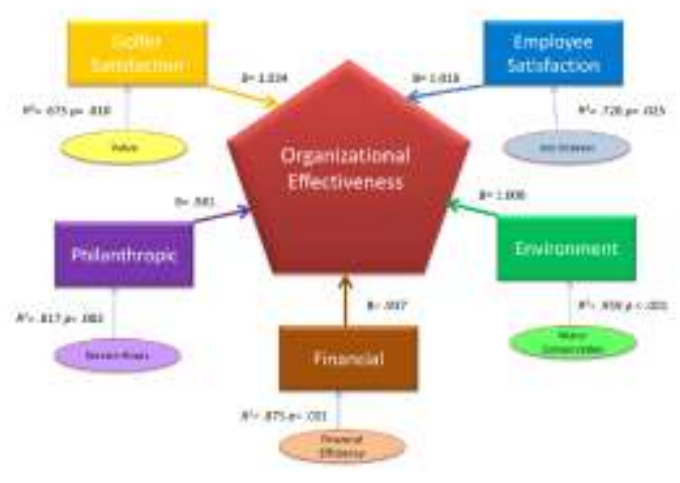

Figure 2 - Organizational Effectiveness

As depicted in figure 2, organizational effectiveness was defined as the sum of five indices including the: financial pillar, environmental pillar, philanthropic pillar, golfer satisfaction pillar, and employee satisfaction pillar. In order to make all of these various "pillars" comparable, each facility's index was converted by pillar to a percentile rank. The sum of each pillar's percentile rank generated an overall Organizational Effectiveness Index (OEI). This data established "effective" verses "less effective" organizations in SWFL. This information was then analyzed to gain further insight into research question (see Figure 1).

The Financial Performance Index (FPI) was predicated on five financial indicators and calculated as follows:

- $\quad$ Financial Efficiency: Revenues/Assets

- $\quad$ Liquidity: 1-(Current Liabilities/Current Assets)

- $\quad$ Solvency: 1-(Liabilities/Assets) 
- $\quad$ Operating Efficiency: 1-(Expenses (less dep.)/Revenues)

- $\quad$ Repayment Capacity:1-(Interest Expense/Revenues)

Since most golf facilities are non-profit, these five indicators were chosen to account for the inherent difference between profit and not for profit organizations. Ratios and inverse ratios were used to insure that larger ratios were favorable and smaller ratios were unfavorable. These common financial statistics were used to establish the overall health and efficiency of a golf facility.

Six environmental factors were used to develop an Environmental Responsibility Index (ERI). The ERI was predicated on the Audubon International (2013) sanctuary certification classifications which include:

- $\quad$ "Environmental Planning

- $\quad$ Wildlife and Habitat Management

- $\quad$ Chemical Use Reduction and Safety

- Water Conservation

- Water Quality Management

- $\quad$ Outreach and Education" (p.1)

The scores for this pillar were calculated using a modified Audubon rubric.

The Organizational Philanthropic Index (OPI) was established using five statistics including:

- $\quad$ Charitable Expense in \$/Total Revenues

- \$ Value Donated Rounds of Golf/ Total Revenues

- $\quad$ Donated Prizes in \$/ Total Revenues

- Value Donated Use of Facility in Hrs/ Total Revenues

- $\quad$ Community Volunteer Hrs/(\# of Employees x 2080)

Since golf facilities vary in size, these statistics were chosen to indicate the relative amount of resources an organization directly contributes to the community.

The Employee Satisfaction Index (ESI) and the Golfer Satisfaction Index (GSI) were established through surveys. The employee and golfer satisfaction surveys were administered for one full week (a traditional golfing cycle) to each golfer and to all Pro Shop Operation and Golf Course Maintenance employees. The population of golfers in SWFL was approximately 30,000 and the population of golf related employees was approximately 3,000. Paper surveys were distributed and returned anonymously (Appendix 1, $2 \& 3$ ). A statistically significant response of 237 golfers (95\% Confidence with a Margin of Error of $+/-5.5 \%$ ) and 121 employees (95\% Confidence with a Margin of Error of $+/-7.5 \%$ ) was achieved (Groch, 2013).

Data on employee satisfaction was collected using “An Index of Job Satisfaction” (Brayfield \& Rothe, 1951) with 18 questions on a Likert four-point scale, ranging from strongly agree to disagree. A 4 point scale was selected in order to minimize the social desirability bias (Garland, 1991) and provide a theoretical construct validity of .90 (Ray, 1982). According to Brayfield \& Rothe (1951), a highly correlated, reliability coefficient of .87 can be obtained with this methodology. In addition, the Brayfield \& Rothe (1951) survey has been validated numerous times and is commonly used (Judge \& Klinger, 2007). Items $1,2,5,7,9,12,13,15,17$ were highly correlated with job satisfaction and were assigned the following values: Strongly Agree- 4 points, Agree- 3 points, Undecided- 2 points, Disagree- 1 point (Brayfield \& Rothe, 1951). Items 3, 4, 6, 8, 10,11, 14, 16, and 18 were highly correlated with job dissatisfaction and were scored in reverse order (Brayfield \& Rothe, 1951). The sum of these values indicated the overall level of an employee's job satisfaction and produced an Employee Satisfaction Index (ESI). Since the job satisfaction survey used for this research was by Brayfield (1951) and has been tested numerous times for validity and reliability; no psychometric tests were performed. 
In order to facilitate an integrated importance /performance index that could be used as an overall expression of golfer satisfaction, the following Golfer Satisfaction Index (GSI) was used by Groch (2013):

$G S I=\sum_{j=1}^{18}\left[i_{j}\left(2.5 p_{j}-7.6\right)\right] / n$

(where $i=$ importance, $p=$ performance)

According to Groch (2013) the model achieved a "goodness of fit" coefficient of determination of .983 and therefore has been accepted as an appropriate tool for measuring satisfaction. However, the golfer satisfaction survey had not been tested for reliability and validity. According to Jackson (2012) one of the most often used and obvious ways of establishing reliability is to employ test/retest reliability. A test/retest was performed. The reliability coefficient $\left(\mathrm{r}^{2}\right)$ for the test/retest was .86. Since according to Jackson (2012) a reliability coefficient of .70 or higher is considered a strong correlation, the survey was deemed to be reliable. In addition, Jackson (2012) states "to determine whether a test has content validity you should consult experts in the area being tested" (p. 72). Therefore, the content validity of the survey was reviewed by two PGA professionals and professors at Hodges University whom deemed the survey to be valid.

\section{ORGANIZATIONAL EFFECTIVENESS}

Organizational effectiveness was defined by Five Pillars: Financial, Environmental, Philanthropic, Customer Satisfaction, and Employee Satisfaction. These Five Pillars were used to calculate an overall Organizational Effectiveness Index (OEI) that could be used to rank or distinguish effective organizations in SWFL from less effective organizations in SWFL (Figure 3). The OEI was the sum of the percentile rankings of the Five Pillars for each golf facility. Using the bootstrap method, the mean OEI was $2.377, \mathrm{SE}=.360,95 \% \mathrm{CI}(1.640,3.015)$ and produced the following hierarchy of organizationally effective facilities:

\begin{tabular}{cc} 
Facility & OEI \\
\hline A1 & 3.774 \\
G1 & 3.443 \\
G2 & 3.352 \\
R1 & 3.332 \\
C1 & 2.996 \\
M1 & 2.667 \\
T1 & 1.990 \\
L1 & 1.322 \\
B1 & 0.777 \\
P1 & 0.222
\end{tabular}

The Financial Pillars were based upon the following result: Financial Efficiency $(M=.713, S E=.177)$, Liquidity Ratio $(M=.143, S E=.092)$, Solvency Ratio $(M=.586, S E=.083)$, Operating Efficiency $(M=.042, S E=$ $.020)$, and Repayment Capacity $(M=1.000, S E=.000)$. The Organizational Philanthropic Index (OPI) resulted in: Charitable Expense $(M=.003, S E=.000)$, Donated Rounds $(M=.002, S E=.000)$, Donated Prizes $(M=.001, S E=$ $.000)$, Use of Facility $(M=.003, S E=.000)$, and Volunteer Hours $(M=.003, S E=.001)$. The Environmental Responsibility Index (ERI) was based on an Audubon International rubric and produced the following: Environmental Planning $(M=3.000, S E=.345)$, Wildlife and Habitat Management $(M=3.000, S E=.345)$, Chemical Use Reduction and Safety $(M=3.100, S E=.331)$, Water Conservation $(M=3.300, S E=.347)$, Water Quality Management $(M=2.900, S E=.346)$, Outreach and Education $(M=2.900, S E=.346)$. 
The Employee Satisfaction Index (ESI) was predicated on job satisfaction questionnaires. Among the 10 country clubs that participated in the research, 121 employees $95 \% \mathrm{CI},[+/-7.5 \%]$ completed the job satisfaction survey. Sixty-one percent of respondents worked in the pro-shop, 39\% worked in golf maintenance; $79 \%$ were men, $16 \%$ were women, and 5\% did not answer the gender question; 77\% spoke English and 23\% were Spanish speaking.

The highest job satisfaction score for the sample of golf employees in SWFL was 71 out of a possible 72, while the lowest score recorded was 40 with a lowest possible score of 18 . Sixty-six percent of total employee responses to all questions were either 3 or 4 . The mean job satisfaction index score for SWFL was 59.44 and the standard deviation was 5.285. The median index for the region was 59.01. Frequency analysis of overall employee satisfaction indices indicated a normal distribution with a slightly negative skew of -.789 and kurtosis of 2.52. .

Two hundred thirty-seven golfers completed the Golfer Satisfaction Survey 95\% CI [+/-5.5\%]. Of the 10 country clubs that participated in the golfer's survey, $72 \%$ were men, $29 \%$ were women and $1 \%$ did not respond to the gender question. The breakdown of participants by type of facility was: 56\% Golf Community, 20\% Public, 19\% Private and 5\% Resort. The average handicap for all facilities was 21 and the average amount of rounds per week was 2.9. The average male handicap was 19.5 and the average female handicap was 25 . Lower handicappers (21 and under) played an average of 3.3 rounds per week, while higher handicappers played 2.6 times per week. Finally, more frequent golfers ( 3 or more times per week) had significantly lower average handicaps, 19.6 versus 23.6 for less frequent golfers (Groch, 2013).

The Golfer Satisfaction Index (GSI) was based on Golfer Satisfaction surveys and combined both variables of golfer expectation (i.e. importance) and an evaluation of perceived performance. Golfers rated the operational performance of their facilities on a 5 point scale: $1=$ completely dissatisfied, $2=$ somewhat dissatisfied, $3=$ neither satisfied nor dissatisfied, 4 =somewhat satisfied, $5=$ completely satisfied. According to Martilla and James (1977), empirical research has demonstrated that customer satisfaction is a function of both expectations related to certain important attributes and a judgment of attribute performance. Therefore, the following formula was used to integrate these two variables into a working model that would generate a Golfer's satisfaction Index (Groch, 2013):

$G S I=\sum_{j=1}^{18}\left[i_{j}\left(2.5 p_{j}-7.6\right)\right] / n$

(where $i=$ importance, $p=$ performance)

The resulting satisfaction indices were analyzed in Excel and SPSS. The mean overall golfer satisfaction in SWFL was 15.1 on a scale of 24.5 to -25.5 . The lowest average rating was 1.2 and the highest average rating was 24.5 . The standard error of the mean was .3324 and standard deviation was 5.117. Skewness was recorded at -.292 and kurtosis was -.542 indicating a normal distribution with a slightly negative skew.

Finally, it should be noted that the Financial Performance Index (FPI) $\left(r^{2}=.879, p=.001\right)$, Employee Satisfaction Index (ESI) $\left(r^{2}=.717, p=.020\right)$, and the Golfer Satisfaction Index (GSI) $\left(r^{2}=.818, p=.004\right)$ correlated most highly with overall Organizational Effectiveness. Only the Organizational Philanthropic Index (OPI) $\left(r^{2}=.555\right.$, $p=.099)$ and Environmental Responsibility Index (ERI) $\left(r^{2}=.581, p=.078\right)$ did not show any significant correlation to the OEI with $p>.05$. Furthermore, in order to determine the influence of the elements that constitute an effective organization, multiple regression analyses were performed on the OEI variables. The resulting beta coefficients of $\mathrm{x}_{1}: \beta=.937 ; \mathrm{x}_{2}: \beta=.981 ; \mathrm{x}_{3}: \beta=1.008, \mathrm{x}_{4}: \beta=1.018$, and $\mathrm{x}_{5:}: \beta=1.034$ produce a Path Analysis of Effective Organizations (Figure 2) where:

$\mathrm{x}_{1}=$ Financial Performance Index

$\mathrm{x}_{2}=$ Organizational Philanthropic Index

$\mathrm{x}_{3}=$ Environmental Responsibility Index

$\mathrm{x}_{4}=$ Employees Satisfaction Index

$\mathrm{x}_{5}=$ Golfer Satisfaction Index 


\section{THE EFFECTIVE ORGANIZATION}

As postulated here, effective golf organizations in Southwest Florida are defined by five "Pillars": Financial Effectiveness, Environmental Effectiveness, Philanthropic Effectiveness, Customer Satisfaction, and Employee Satisfaction. Effective golf organizations in SWFL are highly customer driven (GSI > 15.1, $\beta=1.034$ ). They satisfy their golfers by having extremely courteous personnel (Courtesy: $\beta=.440$ ), provide quality products at reasonable prices (Products: $\beta=.407$ ), have excellent course conditions (Golf Course: $\beta=.202$ ), good pace of play (Pace: $\beta=.156)$ and add value to everything they do (Value: $\beta=.152)$. They have happy employees (ESI $>59.44, \beta=$ 1.018). They promote job enjoyment (Enjoy Job: $\beta=.481$ ) and work enthusiasm (Work Enthusiasm: $\beta=.218$ ) through job interest (Job Interest: $\beta=.230$ ). Specifically, they maintain morale by practicing cross-training and job enrichment.

Effective organizations are dedicated to the environment (ERI $>18.2, \beta=1.008$ ). They use Audubon International Environmental Standards (AIES) (2013). For example, they prioritize water conservation $\left(r^{2}=.959, p^{<}\right.$ .001 ) and "train employees to employ conservation techniques, identify water sources used for irrigation and drinking water, and train key staff to operate and manage the irrigation system" (AIES, p. 5) efficiently. They engage in environmental planning $\left(r^{2}=.933, p<.001\right)$, conduct site assessments "to evaluate current environmental management practices, and identify strengths and liabilities; develop (maps) of the course that highlights wildlife habitats, water resources, and management zones to use for planning and project implementation; and set goals and priorities and assign responsibilities to staff' (AIES, p. 1). They practice wildlife and habitat management $\left(r^{2}=\right.$ $.933, p<.001)$ by identifying "core habitats, such as mature woodlands, wetlands, or stream corridors, and special habitat concerns, such as endangered or threatened species, on the property; train staff to understand that management practices may positively enhance or adversely impact wildlife species and habitats; (and maintain an) on-going written inventory of bird and mammal species to document and track wildlife use of the property" (AIES, p. 2).

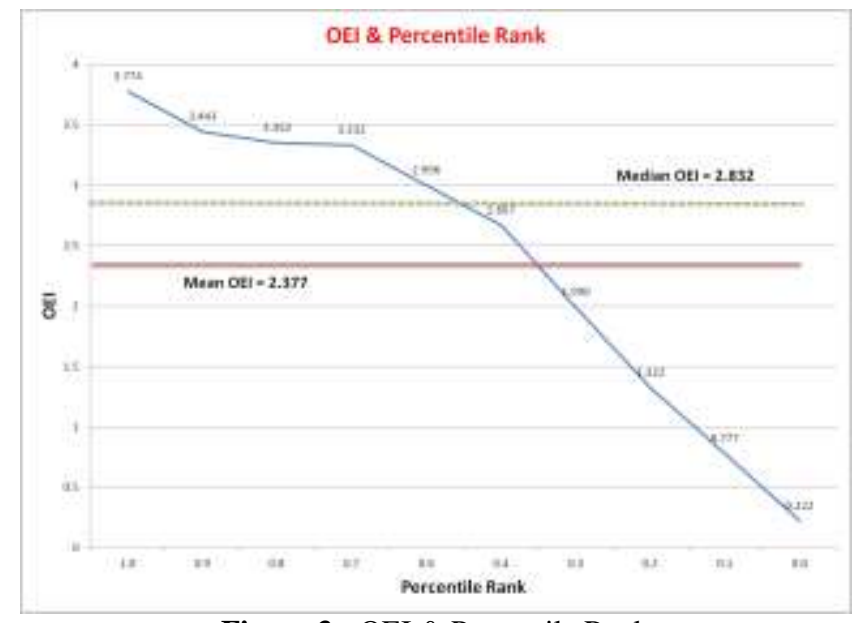

Figure 3 - OEI \& Percentile Rank

Effective organizations give back to the community (OPI $>.012, \beta=.981$ ). They donate the use of their facilities by giving free access to charities and junior golf programs and they support charities and junior golf programs by allowing golf personnel to serve as volunteers on company time $\left(r^{2}=.817, p=.002\right)$.

While most golf facilities are not for profit (NCCS, 2013), the effective golf facility possesses strong financial statements (FPI $>2.484, \beta=.937)$. They are extremely financially efficiency (Revenues/Assets $>.713: r^{2}=$ $.875, p=.001$ ) and they are very solvent by possessing a high solvency ratio [1-(Liabilities/Assets) $>.586: r^{2}=.612$, $p=.050]$. In short, they operate responsibly, holistically and with an understanding that the organization is a "social organism" requiring the harmonious balance of the five Pillars in order to maintain health and survival. 


\section{CONCLUSION}

Effective golf organizations in SWFL are balanced. They possess superior financials, customer service, employee satisfaction, charity, and environmental practices. In fact $80 \%$ of effective organizations surveyed were among the top performers in at least 4 out of the 5 Pillars whereas only $20 \%$ of less effective organizations were among the top performers in more than 1 Pillar. This suggests that good management is universal. In other words, when a facility's management team is effective, they are effective in multiple areas. Conversely, ineffective organizations tend to be ineffective in multiple areas. This also suggests that the Pillars influence each other. For example the Financial Performance (FPI) is significantly correlated with Customer Service (GSI) $\left(r^{2}=.886, p=.001\right)$, and Employee Satisfaction $\left(r^{2}=.596, p=.050\right)$.

The implications of these finding could be significant to auditors searching for indicators of fraud, or managers looking for trends, or board of directors (BOD) trying to assess the competency of the management team. It also suggests that there is interdependence between the five pillars and that to ignore one pillar may be at the expense of the other pillars.

Finally, since most golf facilities are not for profit and are operated for the enjoyment of the patrons, the big question that needs to be addressed is how does one measure quality of life? BODs that focus strictly on financial performance are missing the big picture. Unless they take a holistic view of the organization: financially, environmentally, philanthropically, customer satisfaction, and employee satisfaction, the facility may never achieve its true potential and deprive its patrons of the experiences they deserve.

\section{AUTHOR INFORMATION}

Joseph M. Groch is a member of the PGA of America and holds a Master of Professional Studies degree from Hodges University. He is the Director of Golf at the Glades Golf \& Country Club in Naples, Florida and an Adjunct Professor at Florida Gulf Coast University. He earned a B.S. in Accounting from St. Joseph's University in Philadelphia and has published several articles and books related to the golf industry.

\section{REFERENCES}

1. Audubon International, (2013). Audubon cooperative sanctuary program for golf. Standard Environmental Management Practices. Retrieved from: http://www.auduboninternational.org/acspgolf

2. Avolio, B. J. (2007). Promoting more integrative strategies for leadership theory-building. American Psychologist, 62(1), 25 DOI: 10.1037/0003-066X.62.1.25

3. Bratton, J., Grint, K., \& Nelson, D.L. (2005). Organizational leadership. Mason, OH: South-Western Publishing

4. Brayfield, A., \& Rothe, H. (1951). An index of job satisfaction. Journal of Applied Psychology, 35(5), 307311. doi: $10.1037 / \mathrm{h} 0055617$.

5. Brazel, J., Hall, N., Jones, K., \& Zimbelman, M. (2005,). What Can Nonfinancial Performance Measures Tell Us About the Likelihood of Fraud?. In American Accounting Association Auditing Section 2006 Midyear Conference, Los Angeles, CA.

6. Brody, E. (1995). Agents without principals: The economic convergence of the nonprofit and for-profit organizational forms. NYL Sch. L. Rev., 40, 457.

7. Corporate Leadership Council (2013). Retrieved from: https://clc.executiveboard.com/Public/CurrentResearch.aspx

8. Council on Foundations, (2000). Measuring the business value of corporate philanthropy. Walker Information. Retrieved from: http://www.cof.org/files/Documents/Corporate_Grantmaking/Measurement/Measuring_t e_Business_Value_of_Corp_Phil-Executive_Summary.pdf

9. Edwards, W. (1998). Òn interpreting financial performance measures, Purdue Decision Maker, 11 (3-56)

10. Elkington, J. (1994).Towards the sustainable corporation: win-win-win business strategies for sustainable development, California Management Review. 36, (2) 90-100. 
11. Frost, S. (2013). List of non-financial performance objectives. Small Business Chronicle. Houston: Demand Media

12. Groch, J.M. (2013). GSI: Key to golfer retention. International Journal of Social Science Research, 1 (1), 38-51

13. Henderson, D. (2001). The case against corporate social responsibility. Policy: St. Leonards 17(2), 28-32

14. Ittner, C. D., \& Larcker, D. F. (1998). Are nonfinancial measures leading indicators of financial performance? An analysis of customer satisfaction. Journal of accounting research, 36, 1-35.

15. Ittner, C. D., \& Larcker, D. F. (2000).Non-financial performance measures: What works and what doesn't. Knowledge@Wharton,12(6)

16. Jaffee, C. L. (2001), Building the skill sets for the new economy. Employment Relations Today, 27: 9-22. doi: 10.1002/ert.13

17. Jackson, S.L., (2012). Research Methods and Statistics: A Critical Thinking Approach (4th ed.), Belmont, CA: Wadsworth

18. Karnani, A. (2010). The case against corporate social responsibility. Wall Street Journal, 23, 1-5

19. Katz, J (2012). Executives Fear Leadership Shortage. IndustryWeek. 3 (12).

20. Likert, R. (1961). New patterns of management. New York: McGraw-Hill

21. Mooney, C. Z., \& Duval, R. D. (1993). Bootstrapping: A nonparametric approach to statistical inference , Sage Publications. 7 (95).

22. National Golf Foundation, (2010). Operating \& financial performance profiles of 18-hole golf facilities in the U.S. Operating and Financial Performance Profiles National Summary - 2010. 7(10) 1-5. Retrieved from http://www.marketresearch.com/National-Golf-Foundation-v1023/.

23. Professional Golfers Association of America (2012). Know your customer. Golf 2.0, Retrieved from: http://www.pgalinks.com/professionals/content/index.cfm?ctc $=6459 \& \mathrm{fr}=267$.

24. Shah, A.M. (2005).The foundations of successful strategy implementation: Overcoming the obstacles. Global Business Review, 6(6), 293-302,

25. Slaper, T. F., \& Hall, T. J. (2011). The triple bottom line: what is it and how does it work?. The Indiana Business Review, 86(1), 4-8.

26. Thompson, P., \& McHugh, D. (2002). Work organizations: a critical introduction, $3^{\text {rd }}$ ed. Basingstoke, UK: Palgrave

27. Tucker, E. (2013). What is behind the leadership shortage? Human Capital Institute. 3(13)

28. Winston, B. E., \& Patterson, K. (2006). An integrative definition of leadership. International Journal of Leadership Studies, 1(2), 6-66.

29. Yuchtman, E., \& Seashore, S. E. (1967). A system resource approach to organizational effectiveness. American Sociological Review, 891-903 


\section{NOTES}

